\title{
Naar een uniforme formule voor voederconversie via participatief onderzoek in de varkenshouderij
}

\author{
${ }^{1,2}$ I. Chantziaras, ${ }^{1}$ J. Van Meensel, ${ }^{3}$ S. De Smet, ${ }^{2}$ D. Maes, ${ }^{1}$ S. Millet \\ ${ }^{1}$ ILVO, Scheldeweg 68, B-9090 Melle \\ ${ }^{2}$ Faculteit Diergeneeskunde, Universiteit Gent, Salisburylaan 133, B-9820 Merelbeke \\ ${ }^{3}$ Varkensloket, Scheldeweg 68, B-9090 Melle
}

\section{INLEIDING}

Door de toenemende druk op de economische marges in de varkenshouderij neemt het belang van efficiënter produceren toe. De grootste kost bij het afmesten van vleesvarkens is het voeder, met een gemiddeld aandeel van ongeveer $75 \%$ in de totale afmestkosten (Departement Landbouw en Visserij). De voederkosten hangen af van de voederprijzen, maar ook van de voederconversie (VC), die ruwweg aangeeft hoeveel voeder nodig is om $1 \mathrm{~kg}$ groei te verkrijgen. Een verlaging van de $\mathrm{VC}$ resulteert in een economische winst en een reductie in de milieubelasting, door een verminderde behoefte aan voeder en een daling van de excretie. Ondanks het feit dat VC zo'n belangrijke parameter is, bestaat er geen uniforme berekening. ILVO en UGent gingen daarom samen met de sector op zoek naar een geschikte parameter en lanceerden een bijbehorende berekeningstool. Voor een volgende fase zoeken ze varkenshouders die graag willen weten hoe ze hun VC kunnen optimaliseren.

\section{Geen uniforme formule voor voederconversie}

Het ontbreken van een uniforme berekening voor VC maakt het moeilijk voor varkenshouders om in te schatten of ze een goed management voeren. $\mathrm{Er}$ zijn natuurlijk verschillende redenen waarom uniformiteit ontbreekt. Zo is het niet altijd eenvoudig om het levend gewicht van vleesvarkens te bepalen. Daardoor worden soms andere parameters, zoals karkasgewicht, gebruikt die gemakkelijker beschikbaar zijn. Bovendien worden formules vaak aangepast om informatie te bieden die het meest relevant is voor een specifieke varkenshouder of belanghebbende, en houden verschillende formules rekening met verschillende gewichtstrajecten of incorporeren ze sterfte op een verschillende manier.

\section{Multidisciplinariteit als troef}

In het kader van het VLAIO-LA traject "Naar een bedrijfseconomische en milieukundige win-win door efficiënter voedergebruik in de varkenshouderij”, gingen ILVO en UGent op zoek naar een uni- forme berekeningswijze voor VC. Hiervoor werden tal van belanghebbenden uit de sector betrokken in een participatief proces met verschillende overleg- en aftoetsmomenten. In totaal waren negen onderzoekers uit verschillende disciplines (dierwetenschappers, dierenartsen, landbouweconomen) betrokken en 25 belanghebbenden uit de Vlaamse primaire sector, de veevoederindustrie, de farmaceutische sector, fokorganisaties, bedrijven uit distributiesector, academische instellingen, onafhankelijke voorlichting en beleid.

\section{Twee doelstellingen, twee formules}

Het participatieve proces leverde twee verschillende parameters en bijbehorende formules op: karkasgroei per kg voeder en gestandaardiseerde karkasgroei per $\mathrm{kg}$ voeder. Beide plaatsen gewichtstoename in de teller en voedergebruik in de noemer, in tegenstelling tot de meeste bestaande formules voor VC. Op die manier sluiten de parameters beter aan bij conventionele productiviteitsparameters, zoals arbeids- of kapitaalproductiviteit. Daarenboven werd beslist te werken met warm karkasgewicht in plaats van levend gewicht, omdat dit standaard wordt gemeten in Vlaamse slachthuizen. Ook onze buurlanden en de meeste andere Europese landen werken met warm karkasgewicht. Karkasgroei per kg voeder dient als een objectieve weergave van de prestaties van de vleesvarkens in een productieronde. De gestandaardiseerde karkasgroei per kg voeder corrigeert voor sterfte (aan de hand van een lineair model) en is representatief voor een gewichtstraject van $25-115 \mathrm{~kg}$ (levend gewicht). Deze laatste formule maakt dat vergelijkingen tussen bedrijven veel eenvoudiger en eenduidiger zijn.

\section{Aan de slag met de gebruiksvriendelijke webtool}

Om de karkasgroei per kg voeder en gestandaardiseerde karkasgroei per $\mathrm{kg}$ voeder te berekenen werd een webtool gelanceerd (https://varkensloket.be/ tools/karkasgroei). Die webtool maakt gebruik van zes gegevens die de gebruiker moet ingeven: het gemiddeld opleggewicht van de biggen, het aantal opge- 


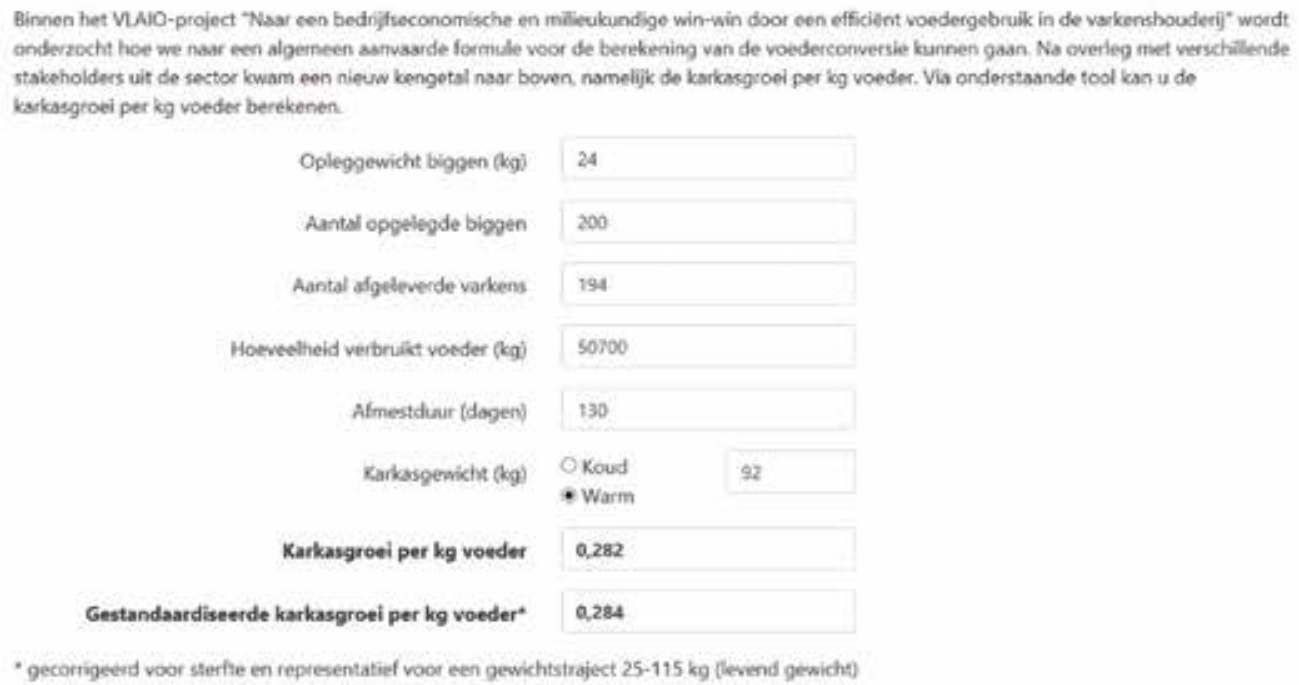

Figuur 1. Webtool om karkasgroei te bepalen.

legde biggen, het aantal afgeleverde varkens, de totale hoeveelheid voeder gebruikt tijdens de afmestperiode, de afmestduur en het gemiddelde karkasgewicht (warm of koud). Figuur 1 geeft een voorbeeld van de berekening.

In dit voorbeeld ligt de gestandaardiseerde karkasgroei per $\mathrm{kg}$ voeder 0,002 hoger dan de karkasgroei per kg voeder. Dit komt door de vertaling van het geobserveerde gewichtstraject $24-113 \mathrm{~kg}$ naar het standaardtraject $25-115 \mathrm{~kg}$ en het in rekening brengen van de lineaire correctie voor sterfte. Deze standaardisatie maakt het mogelijk om verschillende bedrijven te vergelijken of de prestaties van de boerderij in de tijd op te volgen.

Om de lezer vertrouwd te maken met de nieuwe formules, volgt nog een voorbeeld: gebaseerd op de huidige gemiddelde Vlaamse cijfers (Departement Landbouw en Visserij) werd in de webtool een gestandaardiseerde karkasgroei per kg voedingswaarde van ongeveer 0,295 bekomen.
Nieuwe formules, nieuwe perspectieven - Deelname aan het onderzoek

Komen tot nieuwe formules was één doelstelling van het onderzoek. Daarnaast willen ILVO en UGent nagaan welke factoren de karkasgroei per $\mathrm{kg}$ voeder beïnvloeden en hoe een varkenshouder kan inspelen op deze factoren. Hiervoor zijn we op zoek naar bedrijven met een vleesvarkenstak die willen meewerken en graag meer zouden willen weten over hoe ze hun karkasgroei per kg voeder kunnen optimaliseren. Deelnemers moeten bereid zijn tot een gesprek (maximum 2 uur) waarin een vragenlijst wordt ingevuld. Uiteraard garanderen de onderzoekers volledige confidentialiteit en een anonieme verwerking van de gegevens.

Voor vragen of deelname contacteer dierenarts Willem Neyrinck (willem.neyrinck@ugent.be, 09 26475 40) of dierenarts Ilias Chantziaras (ilias.chantziaras@ilvo.vlaanderen.be, 092722601 ). 